\title{
Rancang Bangun Alat Pendeteksi Kebusukan Telur Menggunakan Metode Fuzzy Logic Berbasis Mikrokontroler Arduino Nano 328
}

\author{
David Christover ${ }^{1^{*}}$, Adhe Yusphie Panca T.S. ${ }^{2}$, Jordan Ananda Purnomo, S.T $^{3}$, Muhammad Muttaqin \\ Yusup 4 \\ ${ }^{1,2,3,4}$ Institut Teknologi Kalimantan, Balikpapan \\ *E-mail: christoverdavid@gmail.com
}

\begin{abstract}
Abstrak
Telur merupakan salah satu sumber protein bagi masyarakat Indonesia dan selalu menjadi pilihan utama dalam memenuhi kebutuhan pangan sehari-hari. Hal ini dikarenakan pengolahannya yang praktis dan harganya yang cenderung relatif murah jika dibandingkan dengan sumber protein hewani lainnya. Saat ini kebutuhan telur ayam nasional telah mencapai $65 \%$ dengan didominasi oleh kategori telur ayam ras. Diprediksi bahwa kebutuhan telur secara nasional akan meningkat hingga tahun 2021 sebesar 4,87\% dengan tingkat konsumsi sebesar 4,18\% per tahun. Meskipun seperti itu, dalam pemilihan jenis telur yang berkualitas dari produsen, penjual dan terhadap konsumen masih terbilang konvensional dan belum terjamin apakah telur tersebut layak dikonsumsi atau tidak sehingga diperlukan adanya metode baru yang lebih efisien dan mengetahui ciri-ciri kualitas telur yang baik. Berdasarkan latar belakang tersebut, maka dibentuklah sebuah alat praktis yang mudah digunakan bagi pedagang konvensional. Alat ini bekerja dengan menggunakan sensor BH1750 dan MQ-2 sebagai parameter dalam penentuan telur busuk yang kemudian diolah dengan menggunakan mikrokontroller Arduino-nano, selanjutnya pengolahan data tersebut menggunakan kecerdasan buatan fuzzy logic berdasarkan parameter yang telah disusun dari fungsi keanggotaan setiap parameter yang telah didapatkan dari sensor. Penelitian ini dilakukan dengan melakukan pengumpulan informasi terlebih dahulu, lalu melakukan survei ke lokasi yang berupa pasar tradisional untuk mencari telur yang diambil secara acak dengan pengujian 3 sampel telur.Berdasarkan hasil dari tiga kali pengujian terhadap 3 sampel telur yang diambil secara acak,didapatkan bahwa telur 2 dengan nilai Ro sebesar sebesar 4,29 K.Ohm, 4,53 K.Ohm dan 4,79 K.Ohm dan memiliki nilai intensitas cahaya sebesar 10,00 lux dan 5,00 lux adalah telur yang memiliki kualitas terbaik dibandingkan dengan 2 telur lainnya.
\end{abstract}

Kata kunci: Cahaya, Fuzzy Logic, Telur

\begin{abstract}
Eggs are a source of protein for the people of Indonesia and are always the main choice in meeting daily food needs. This is because the processing is practical and the price tends to be relatively cheap when compared to other animal protein sources. Currently the need for national chicken eggs has reached 65\%, dominated by broiler eggs. It is predicted that the need for eggs nationally will increase until 2021 by $4.87 \%$ with a consumption level of $4.18 \%$ per year. Even so, in the selection of quality eggs from producers, sellers and consumers it is still fairly conventional and not guaranteed whether the eggs are suitable for consumption or not, so a new method is needed that is more efficient and knows the characteristics of good egg quality. Based on this background, a practical tool that is easy to use for conventional traders is formed.This tool works by using BH1750 and MQ-2 sensors as parameters in determining rotten eggs which are then processed using Arduinonano 328 microcontroller, then processing the data using fuzzy logic artificial intelligence based on parameters that have been compiled from the membership function of each parameter that has been obtained from sensor. This research was conducted by collecting information first, then conducting a survey to a location in the form of a traditional market to find eggs taken randomly by testing 3 egg samples.Based on the results of three tests on 3 egg samples taken randomly, it was found that egg 2 with a Ro value of 4.29 K.Ohm, 4.53 K.Ohm and 4.79 K.Ohm and had a value of light intensity of 10.00 lux and 5.00 lux are eggs that have the best quality compared to 2 other eggs.
\end{abstract}

Keywords: Egg, Fuzzy Logic, Light 


\section{Pendahuluan}

Saat ini kebutuhan telur ayam nasional telah mencapai $65 \%$ dengan didominasi oleh kategori telur ayam ras. Diprediksi bahwa kebutuhan telur secara nasional akan meningkat hingga tahun 2021 sebesar 4,87\% dengan tingkat konsumsi sebesar $4,18 \%$ per tahun [1]. Di Kota Balikpapan sendiri juga memiliki masyarakat yang selalu memenuhi kebutuhan sehari-harinya dengan telur sehingga akan terus meningkat di pasar tradisional maupun pasar modern. Meskipun seperti itu, dalam pemilihan jenis telur yang berkualitas dari produsen dan penjual terhadap konsumen masih terbilang konvensional dan belum terjamin apakah telur tersebut layak dikonsumsi atau tidak sehingga diperlukan adanya metode baru yang lebih efisien dan mengetahui ciri-ciri kualitas telur yang baik.

Berdasarkan latar belakang tersebut, maka dibentuklah sebuah alat praktis yang mudah digunakan bagi pedagang konvensional dengan menggunakan mikrokontroller Arduino-nano 328. Selanjutnya pengolahandatatersebut menggunakan kecerdasan buatan fuzzy logic berdasarkan parameter yang telah disusun dari fungsi keanggotaan setiap parameter yang telah didapatkan dari sensor.

\section{Metodologi}

Metode yang digunakan dalam penelitian tersebut dapat digambarkan pada Flowchart di bawah ini sebagai berikut.

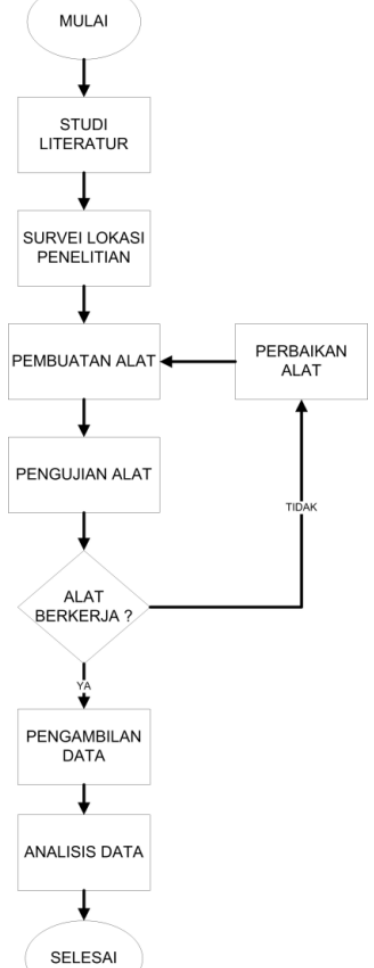

Gambar 1. Flowchart Metode Penelitian

\subsection{Pengumpulan Informasi}

Metode yang digunakan dalam studi literatur adalah dengan mencari sumbersumber data dari buku dan jurnal yang berkaitan dalam menunjang proses penelitian tersebut dengan instrumen yang digunakan adalah berupa sumber cahaya yang berasal dari LED, sensor cahaya BH1750FVI, sensor MQ2, Arduino Nano 328 dan referensi yang berkaitan dengan tema penelitian yang dijalankan [2][3].

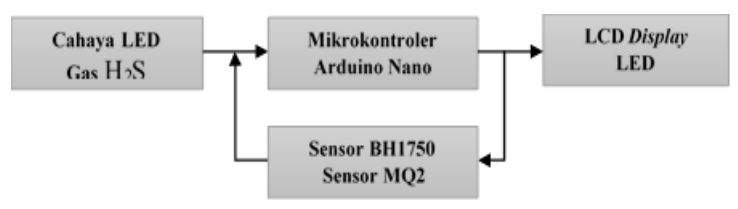

Gambar 2. Diagram Blok Alat

Perancangan lunak dilakukan dengan pembuatan program kecerdasan buatan (Artificial Intelligence) menggunakan fuzzy logic dan sistem embedded fuzzy logic ke Arduino Nano 328. Perancangan perangkat lunak bertujuan untuk menentukan setiap alur kerja dari sistem pembusukan telur secara otomatis. Setiap masukan yang diterima akan diatur oleh fuzzy logic yang selanjutnya akan diproses untuk menentukan eksekusi pada bagian keluaran.

Dengan menggunakan metode fuzzy logic model Mamdani pada Matlab maka terdapat 3 variabel pada penelitian ini yaitu cahaya sinar laser, $\mathrm{H}_{2} \mathrm{~S}$ dan kebusukan telur. Fungsi keanggotaan ditunjukkan pada Gambar 3,4 , dan 5 .

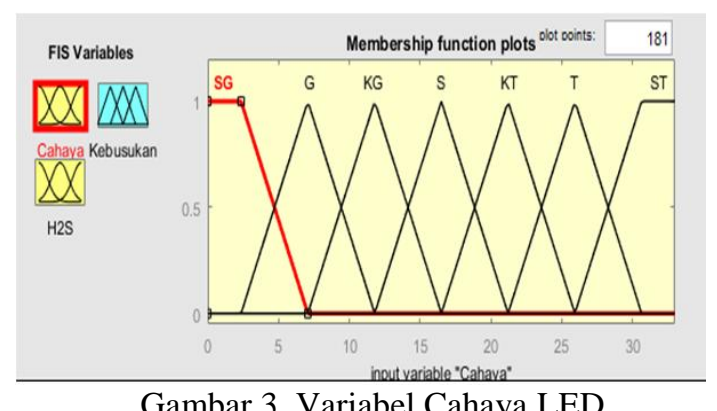

Variabel cahayaterdiri dari 7 fungsi keanggotaan yaitu Sangat Gelap (SG), Gelap (G), Kurang Gelap (KG), Sedang (S), Kurang Terang (KT), Terang (T), dan Sangat Terang (ST). 


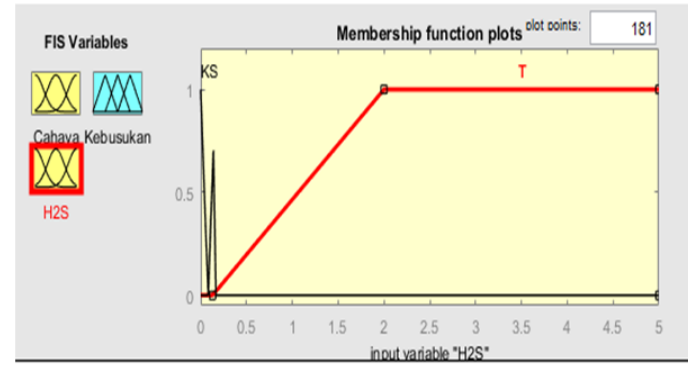

Gambar 4. Variabel $\mathrm{H}_{2} \mathrm{~S}$

Variabel $\mathrm{H}_{2} \mathrm{~S}$ terdiri dari 3 fungsi keanggotaan yaitu Kurang (K), Sedang (S), dan Tinggi (T).

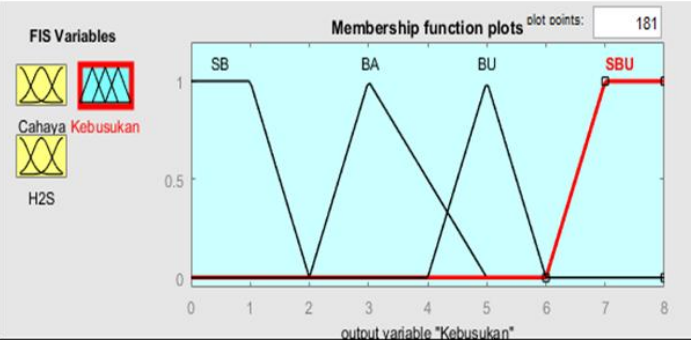

Gambar 5. Variabel Kebusukan

Variabel kebusukan terdiri dari 4 fungsi keanggotaan yaitu Sangat Baik (SB), Baik (B), Busuk (BU) dan Sangat Busuk (SBU).

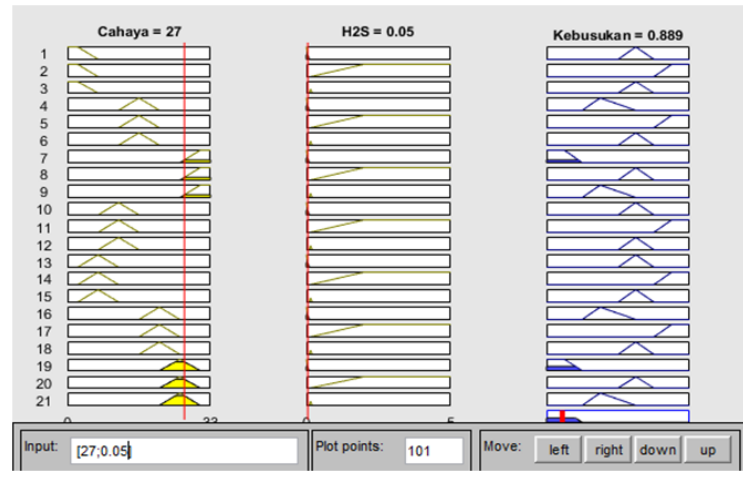

Gambar 6. Rules Viewer Fuzzy Logic

Pada gambar 6 ditunjukan mengenai Rules viewer dimana memiliki tujuan untuk menampilkan hasil olahan dari variabel masukan yaitu cahaya laser dan $\mathrm{H}_{2} \mathrm{~S}$ sehingga menghasilkan variable keluaran yaitu nilai kebusukan telur [4][5].

\subsection{Survei Lapangan}

Dalam penelitian ini perlu dilakukannya pengamatan secara langsung ke lokasi berupa pasar tradisional yang menjual telur dan membeli sampel secara acak telur yang dijual oleh penjual telur tersebut sebanyak 3 telur.

\subsection{Media Penelitian}

Di bawah ini merupakan komponen yang digunakan dalam penelitian tersebut adalah sebagai berikut:

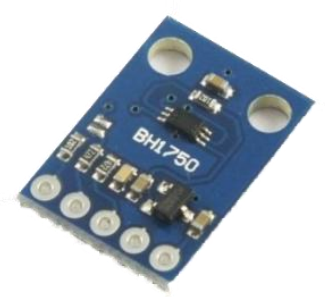

Gambar 7. Sensor BH1750FVI

Sensor BH1750FVI sebagai media utama yang berfungsi menangkap intensitas cahaya yang dipancarkan oleh sumber cahaya.

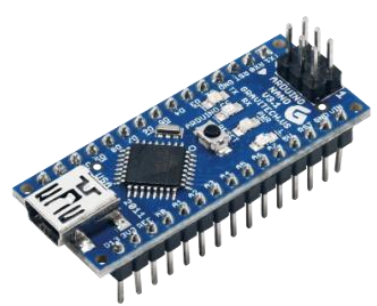

Gambar 8.Arduino Nano 328

Arduino Nano328sebagai mikrokontroler yang mengatur seluruh fungsi kerja seluruh sensor yang digunakan.

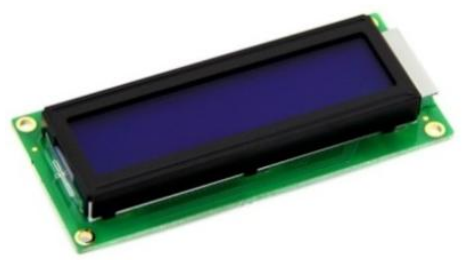

Gambar 9. LCD Display

$L C D$ Display sebagai media yang menunjukkan indikator kualitas telur yang telah diujikan.

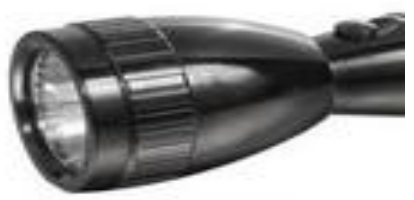

Gambar 10. Sinar LED

Sinar LED ini memiliki fungsi sebagai sumber cahaya yang ditembakkan ke arah telur. 


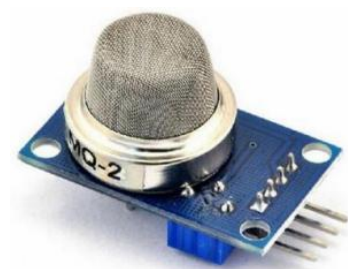

Gambar 11. Sensor MQ2

Sensor MQ2 berfungsi sebagai sensor pendukung untuk mendeteksi gas $\mathrm{H}_{2} \mathrm{~S}$ yang dihasilkan oleh telur.

Berdasarkan komponen - komponen tersebut kemudian disatukan hingga membentuk media akhir untuk penelitian adalah sebagai berikut:

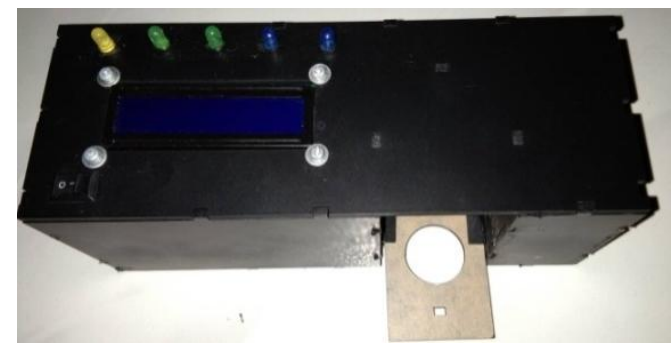

Gambar 12. Alat Uji Kualitas Telur yang telah Disatukan

Proses kerja alat ini adalah dengan meletakkan telur yang akan diuji melalui wadah yang tersedia berbentuk lingkaran berongga lalu memasukkanya ke dalam alat penguji. Setelah itu hidupkan Sinar LED yang berfungsi untuk menembakan cahaya ke arah telur tersebut dan sensor BH1750FVI serta sensor MQ2 akan membaca nilai dari hasil respon intensitas cahaya yang diterima dan aroma $\mathrm{H}_{2} \mathrm{~S}$ yang dikeluarkan oleh tersebut tersebut. Setelah melalui beberapa proses tersebut, indikator telur yang telah dujikan akan muncul di layar LCD Display.

\section{Hasil dan Pembahasan}

\section{a. Visualisasi Kinerja Alat}

Pada alat tersebut terdapat dua jenis kinerja yang masing-masing memiliki fungsi dan tujuannya tersendiri. Visualisasi kinerja tersebut dapat dilihat pada gambar 13 dan gambar 14 sebagai berikut:

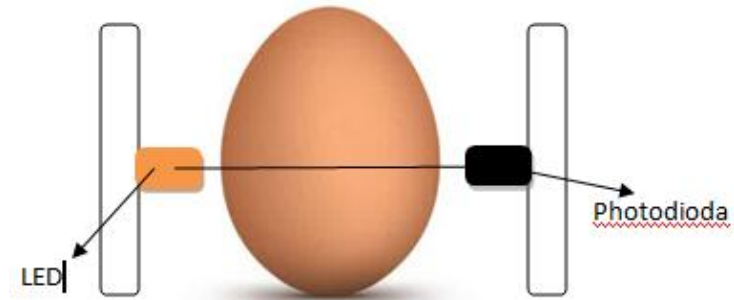

Gambar 13. Visualisasi Alat Terhadap Telur yang Berkualitas Baik

Berdasarkan pada gambar 13, maka dapat ditinjau bahwa jika cahaya yang ditembakan ke arah telur dan intensitas cahaya yang keluar menembus cangkang telur tersebut memiliki kadar nilai yang tinggi kemudian terbaca oleh sensor BH11750FVI akan mendapat respon bahwa telur tersebut memiliki kualitas yang baik.

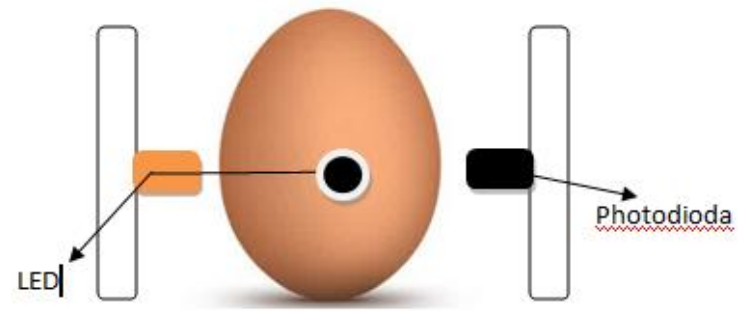

Gambar 14. Visualisasi Alat Terhadap Telur yang Berkualitas Buruk/Busuk

Kemudian berdasarkan pada gambar 14 dapat diperhatikan bahwa terdapat perbedaan reaksi pada cahaya yang telah ditembakan ke arah telur ternyata sulit menembus cangkang telur tersebut dan menyebabkan intensitas cahaya yang dibaca oleh sensor BH11750FVI menjadi sedikit atau rendah nilainya dan akan menghasilkan respon bahwa telur tersebut berkualitas buruk atau busuk [2][6].

\section{b. Pengujian Terhadap 3 Sampel Telur}

Setelah melakukan survei, kemudian dilakukan percobaan ke beberapa telur dan diambil 3 sampel secara acak untuk diketahui kualitasnya seperti pada tabel 1 sebagai berikut:

Tabel 1. Hasil Pengujian Terhadap 3 Telur

\begin{tabular}{ll}
\hline Objek & Keterangan \\
\hline Telur 1 & Tingkat kebusukan sedikit terlihat \\
Telur 2 & Tingkat kebusukan tidak terlihat \\
Telur 3 & Tingkat kebusukan sangat terlihat \\
\hline
\end{tabular}

Jika ditinjau pada Tabel 1, maka dapat diketahui bahwa telur 2 adalah telur yang kualitasnya paling baik diantara 2 lainnya dikarenakan tingkat kebusukannya yang tidak terlihat. 


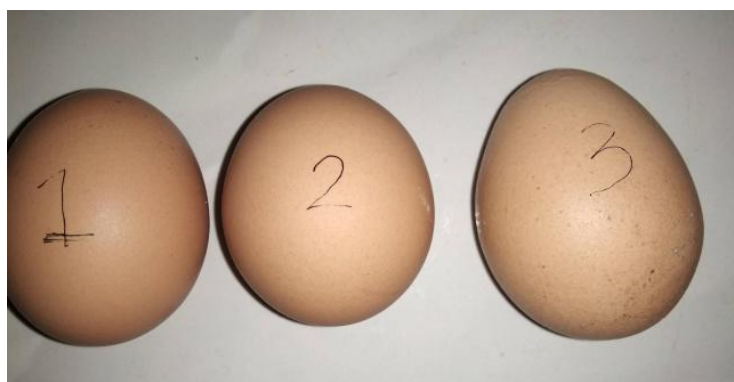

Gambar 10. 3 Sampel Telur yang Diujikan

Gambar 10 adalah 3 sampel telur yang diambil secara acak untuk diujikan terhadap alat detektor kualitas telur untuk diketahui jenis telur yang memiliki kualitas yang baik dan yang buruk atau busuk.

\section{c. Data Hasil Pengujian}

Di bawah ini adalah tabel hasil pengujian yang telah dilakukan terhadap 3 sampel telur yang diambil secara acak yakni sebagai berikut:

Tabel 2. Hasil Pengujian Pertama

\begin{tabular}{|c|c|c|c|c|}
\hline Objek & $\begin{array}{l}\text { Nilai } \\
\text { Ro }\end{array}$ & $\begin{array}{l}\text { Nilai } \\
\mathrm{H}^{2} \mathrm{~S}\end{array}$ & $\begin{array}{l}\text { Nilai } \\
\text { Intensitas }\end{array}$ & Hasil \\
\hline Telur 1 & $\begin{array}{l}4,20 \\
\text { K.Ohm }\end{array}$ & 0 & $5,00 \operatorname{lux}$ & Baik \\
\hline Telur 2 & $\begin{array}{l}4,29 \\
\text { K.ohm }\end{array}$ & 0 & $10,00 \operatorname{lux}$ & Baik \\
\hline Telur 3 & $\begin{array}{l}4,00 \\
\text { K.Ohm }\end{array}$ & 0 & 0 & Busuk \\
\hline
\end{tabular}

Berdasarkan pada tabel hasil pengujian pertama, dapat diketahui bahwa telur 1 yang memiliki nilai Ro sebesar 4,20 K.Ohm memiliki nilai intensitas cahaya sebesar 5,00 lux dengan respon hasilnya adalah baik. Hal ini juga berlaku pada telur 2 yang memiliki nilai Ro sebesar 4,29 K.Ohm memiliki nilai intensitas cahaya sebesar 10,00 lux dengan respon hasilnya adalah baik. Terdapat perbedaan pada telur 3 yang memiliki nilai Ro sebesar 4,00 K.Ohm memiliki nilai intensitas cahaya sebesar 0 lux dengan respon hasilnya adalah busuk.

Tabel 3. Hasil Pengujian Kedua

\begin{tabular}{|c|c|c|c|c|}
\hline Objek & $\begin{array}{l}\text { Nilai } \\
\text { Ro }\end{array}$ & $\begin{array}{l}\text { Nilai } \\
\mathrm{H}^{2} \mathrm{~S}\end{array}$ & $\begin{array}{l}\text { Nilai } \\
\text { Intensitas }\end{array}$ & Hasil \\
\hline Telur 1 & $\begin{array}{l}4,36 \\
\text { K.Ohm }\end{array}$ & 0 & $5,00 \operatorname{lux}$ & Baik \\
\hline Telur 2 & $\begin{array}{l}4,53 \\
\text { K.Ohm }\end{array}$ & 0 & 10,00 lux & Baik \\
\hline Telur 3 & $\begin{array}{l}4,29 \\
\text { K.Ohm }\end{array}$ & 0 & 0 & Busuk \\
\hline
\end{tabular}

Kemudian, pada tabel hasil pengujian kedua dapat diketahui bahwa telur 1 yang memiliki nilai Ro sebesar 4,36 K.Ohm memiliki nilai intensitas cahaya sebesar 5,00 lux dengan respon hasilnya adalah baik. Hal ini juga berlaku pada telur 2 yang memiliki nilai Ro sebesar 4,53 K.Ohm memiliki nilai intensitas cahaya sebesar 10,00 lux dengan respon hasilnya adalah baik. Sama seperti pada tabel 2, disini terdapat perbedaan pada telur 3 yang memiliki nilai Ro sebesar 4,29 K.Ohm memiliki nilai intensitas cahaya sebesar 0 lux dengan respon hasilnya adalah busuk.

Tabel 4. Hasil Pengujian Ketiga

\begin{tabular}{|c|c|c|c|c|}
\hline Objek & $\begin{array}{l}\text { Nilai } \\
\text { Ro }\end{array}$ & $\begin{array}{l}\text { Nilai } \\
\mathrm{H}^{2} \mathrm{~S} \\
\end{array}$ & $\begin{array}{l}\text { Nilai } \\
\text { Intensitas }\end{array}$ & Hasil \\
\hline Telur 1 & $\begin{array}{l}4,72 \\
\text { K.Ohm }\end{array}$ & 0 & $2,00 \operatorname{lux}$ & Busuk \\
\hline Telur 2 & $\begin{array}{l}4,79 \\
\text { K.Ohm }\end{array}$ & 0 & 5,00 lux & Baik \\
\hline Telur 3 & $\begin{array}{l}4,63 \\
\text { K.Ohm }\end{array}$ & 0 & 0 & Busuk \\
\hline
\end{tabular}

Setelah itu, pada tabel hasil pengujian ketiga terdapat perbedaan yang signifikan yaitu dapat diketahui bahwa telur 1 yang memiliki nilai Ro sebesar 4,72 K.Ohm memiliki nilai intensitas cahaya sebesar 2,00 lux dengan respon hasilnya adalah busuk, sangat berbeda dengan hasil 2 pengujian sebelumnya. Pada telur 2 yang memiliki nilai Ro sebesar 4,79 K.Ohm memiliki nilai intensitas cahaya sebesar 5,00 lux dengan respon hasilnya adalah baik. Sama seperti pada tabel 2 dan tabel 3, disini terdapat pada telur 3 yang memiliki nilai Ro sebesar 4,63 K.Ohm memiliki nilai intensitas cahaya sebesar 0 lux dengan respon hasilnya adalah busuk.

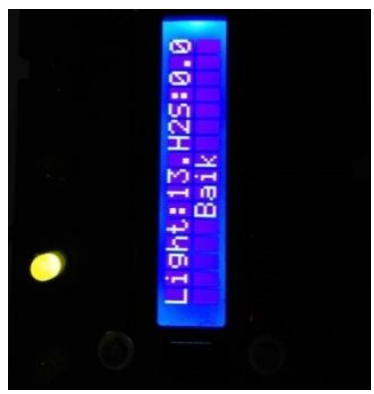

Gambar 11. LCD Display Respon Telur Kualitas Baik

Pada gambar 11 dapat dilihat bahwa tampilan pada telur yang berkualitas baik akan muncul pada layar $L C D$ berdasarkan pada hasil dari proses - proses pengujian yang dilakukan. 


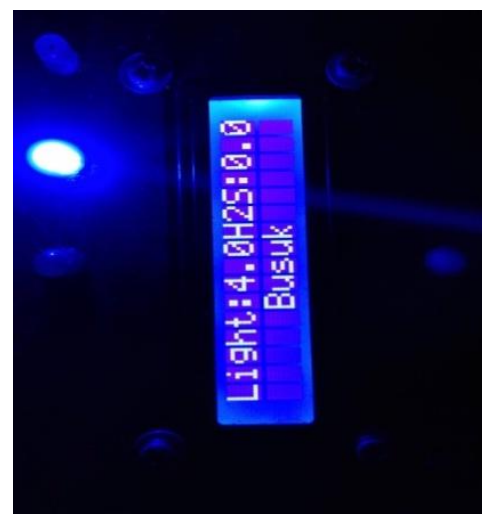

Gambar 12. LCD Display Respon Telur Kualitas Buruk/Busuk

Pada gambar 12 dapat dilihat bahwa tampilan pada telur yang berkualitas buruk atau busuk akan muncul pada layar $L C D$ berdasarkan pada hasil dari proses - proses pengujian yang dilakukan, sama seperti telur yang berkualitas baik.

\section{Kesimpulan}

Berdasarkan pada hasil data dan pembahasan di atas, maka dapat disimpulkan metode fuzzy logic berhasil digunakan dalam pengambil keputusan pada sistem kebusukan telur. Setelah mendapat 3 sampel jenis telur yang diambil secara acak dan melakukan pengujian dengan pengulangan sebanyak $3 \mathrm{kali}$ didapatkan hasil berupa telur 2 yang memiliki nilai Ro sebesar 4,29 K.Ohm, 4,53 K.Ohm dan 4,79 K.Ohm dan memiliki nilai intensitas cahaya sebesar 10,00 lux, 10,00 lux dan 5,00 lux adalah telur yang memiliki kualitas terbaik dibandingkan dengan 2 telur lainnya. Telur 1 awalnya masih memiliki kualitas yang baik mengingat nilai intensitas cahaya yang dimiliki sebesar 5,00 lux selama 2 kali pengujian, namun mengalami penurunan menjadi 2,00 lux pada pengujian ketiga hingga menyebabkan statusnya yang berawal "baik" menjadi "sedikit terlihat busuk". Telur 3 jelas merupakan telur dengan kualitas yang buruk karena semenjak dari pengujian pertama hingga pengujian ketiga memiliki nilai intensitas cahaya sebesar 0 lux atau berkas cahaya tak ada sama sekali menembus cangkang telur dan sensor BH11750FVI tidak membaca adanya berkas cahaya yang masuk hingga menghasilkan respon hasil berupa kualitas busuk.

\section{Saran}

Untuk penelitian selanjutnya, diperlukan setidaknya terdapat 2 indikator tambahan yaitu pengukuran berat telur dan penggantian sensor udara detektor $\mathrm{H}_{2} \mathrm{~S}$ yang lebih sensitif agar pengambilan keputusan yang akan diolah menggunakan fuzzy logic akan jauh lebih akurat dan lebih terjamin efektifitasnya dalam mendeteksi kualitas telur.

\section{Ucapan Terimakasih}

Penulis mengucapkan terima kasih kepada saudara Jordan Ananda Purnomo, Institut Teknologi Kalimantan dan masyarakat penjual telur Balikpapan dalam membantu menjalankan penelitian ini hingga ke titik penyelesaian masalah dan tanpa hambatan sekalipun. Semoga kedepannya hasil penelitian ini dapat dipergunakan sebagaimana mestinya dan dapat membantu untuk pengembangan penelitian lebih lanjut.

\section{Daftar Pustaka}

[1] Kementerian Pertanian Republik Indonesia. "Telur Sumber Makanan Bergizi”. Sukabumi (2010).

[2] Hamdani, Mochammad. "Alat Pendeteksi Telur Menggunakan Sensor Cahaya Dan Bahasa C". Jurnal Teknologi Informasi Vol.5 No.1 (2010).

[3] Rahardi, Sulistyo. "Detektor Kondisi Kelayakan Telur Ayam Kampung Dengan Fuzzy Logic”. Universitas Jember (2013).

[4] Ali, Fuead \& Amran, Noor Azhar. "Development of An Egg Incubator Using Raspberry for Precision Farming”. Malaysian Institute of Information Technology: Univerisiti Kuala Lumpur (2016).

[5] Ramiro, Vargas C. "Egg Candling Analysis Equipment Design: A Safety Solution". Elsevier, Science Direct (2018).

[6] Nugroho, Agung \& Wijayanti, Vinda. "Alat Pendeteksi Telur Berbasis Mikrokontroler PIC16F84". Jurnal Ilmiah Go Infotech Vol. 21 No.1 (2015). 